Людмила УХАЧ, orcid.org/0000-0002-1348-0168 заслужений працівник культури Украӥни, викладач кафедри сочіокультурної діяльності Ужггородського інституту культури і мистецтв (Ужгород, Україна)l_ukhach@murdoch.in

Ніна МАЛИШКА, orcid.org/0000-0003-2778-3474 викладач кафедри мистещьких дисииплін Ужгородського інституту культури і мистеитв (Ужгород, Україна) nina_malysh@uoel.uk

\title{
ОСОБЛИВОСТІ РЕЖИСУРИ ТЕАТРАЛІЗОВАНИХ НАРОДНИХ СВЯТ ТА ОБРЯДІВ
}

\footnotetext{
У даному науковому дослідженні ставиться завдання обговорення кола питань щзодо режисури театралізованих народних свят та обрядових дійств із точки зору наявної сиенічної майстерності та історії театру взагалі. Режисура театральних народних обрядів та свят має глибокі традииії, щуо корінням уходять у культуру формування народного театру, та ї̈ формування відбувалося протягом вельми значного проміжку української історії. Глибоке коріння вітчизняної театральної сцени та традииї украӥнського національного театралізованого дійство зумовлюють якість режисури театральних постановок, різноманітність майстерності театрального виконання та розвинену структуру розвитку основ сценічної майстерності в контексті історії українського театру загалом. Актуальність заявленої тематики дослідження зумовлюється неабияким інтересом, щчо викликає історія режисури театралізованих народних святкових постанов у контексті розвитку українськоі національної театральної сиени та історії розвитку національної культури загалом. Методологія даного наукового дослідження має у своїй основі аналітичний підхід до питань, щчо були винесені у його заголовок. Науковий підхід до вивчення питань формування режисури театралізованих заходів у контексті вивчення історії національного театру сприяє якісному дослідженню тематики та формуванню остаточних висновків на основі отриманих результатів. Головними результатами даного наукового дослідження стали: визначення головних чинників історії розвитку сучасного театру в контексті режисури театральних постанов під час святкування народних свят та обрядовий дійств, а також формування оцінки важливості подальшого розвитку культури театрального мистецтва у сучасні часи. Перспективи подальших досліджень у рамках визначеного кола питань зумовлюються необхідністю визначення характерних рис в історії українського обрядового та театрального мистеитва з формуваннями системо-утворюючих висновків щзодо характеру режисерської діяльності стосовно постановки народних свят та обрядів, а також їхнього впливу на формування театральної культури українського суспільства загалом. Прикладна иінність даного наукового дослідження полягає в можливості втілення на практиці його головних результатів із метою отримання якісної картини щзодо головних етапів розвитку украӥнської театральної сцени.

Ключові слова: театралізовані свята, історія начіонального театру, сценічна майстерність, народні обряди, культура театральної сиени, режисура свят.
} 
Oleksandr KUTSYK, orcid.org/0000-0002-5041-5007

Honored Artist of Ukraine,

Senior Lecturer at the Department of Artistic Disciplines

Uzhhorod Institute of Culture and Arts (Uzhhorod,Ukraine) o.kutsyk6493-4@national-univesity.info

Liudmyla UKHACH, orcid.org/0000-0002-1348-0168

Honored Worker of Ukraine Culture, Senior Lecturer at the Department of Socio-Cultural Activity Uzhhorod Institute of Culture and Arts (Uzhhorod,Ukraine)l_ukhach@murdoch.in

Nina MALYSHKA, orcid.org/0000-0003-2778-3474 Senior Lecturer at the Department of Artistic Disciplines Uzhhorod Institute of Culture and Arts (Uzhhorod,Ukraine)nina_malysh@uoel.uk

\title{
FEATURES OF THE DIRECTION OF THEATRICAL FOLK FESTIVALS AND CEREMONIES
}

\begin{abstract}
This study aims to discuss a scope of issues related to the direction of theatrical folk festivals and ceremonies in terms of existing stage skills and the history of theatre in general. Direction of theatrical folk ceremonies and festivals has deep traditions that are rooted in the culture of development of folk theatre, and its development took place during a very long period of Ukrainian history. The deep roots of the domestic theatre scene and the traditions of the Ukrainian national theatrical action determine the quality of directing theatrical productions, the variety of theatrical performance skills, and the developed structure of the basics of stage skills in the context of Ukrainian theatre in general. The relevance of the stated subject is conditioned by the great interest that causes the history of directing theatrical folk holiday resolutions in the context of the development of the Ukrainian national theatre scene and the history of national culture in general. The methodology of this study is based on an analytical approach to the subject matter. The scientific approach to the study of the development of theatrical activities in the context of studying the history of the national theatre contributes to the qualitative research of the subject and the development of final conclusions based on the results. The main results of this study include: determination of the main factors in the history of modern theatre in the context of direction of theatrical performances during the celebration of folk festivals and ceremonies, as well as evaluation of the importance of further development of theatrical culture in modern times. Prospects for further study within a certain scope of issues are conditioned by the need to identify features in the history of Ukrainian ritual and theatrical art with the development of systemic conclusions regarding the nature of directing activities on the production of folk festivals and ceremonies and their impact on theatrical culture of Ukrainian society. The applied value of this study lies in the possibility of putting its main results into practice in order to obtain a qualitative picture of the main stages of development of the Ukrainian theatre scene.
\end{abstract}

Key words: theatrical holidays, history of the national theatre, stage skills, folk ceremonies, culture of the theatrical stage, direction of holidays.

Постановка проблеми. Театральне мистецтво міцно увійшло до структури загальносвітового мистецтва та вже давно стало однією з його складових частин. Історія сучасного театру нараховує на одне століття, протягом яких відбувався інтенсивний розвиток мистецтва театральної постановки з урахуванням особливостей театрального жанру стосовно розвитку святкових обрядів та формування майстерності їхнього сценічного відображення. Мистецтво, будучи універсальною мовою культури, особливою знаковою системою, використовує різні художні знаки, що володіють певними властивостями. Художні знаки діляться на три групи: знаки-зображення (іконічні знаки), знаки-ознаки (симптоми, індекси, індикатори), умовні знаки (знаки-символи) (Иконникова, Большакова, 2008). Видовищні мистецтва в епоху постмодерну займають все більше місця. Їм відводиться все більше місце у справі духовного, морального, художнього розвитку та виховання, організації їх відпочинку та дозвілля.

Вуличний театр займає особливе місце серед різноманітності жанрів театрального мистецтва. На відміну від класичного сценічного варіанта, актори у вуличному спектаклі можуть зливатися 3 натовпом і розповідати про як там не $є$ повсякден- 
ної реальності. У виставі можуть створюватися фантастичні світи та використовуватися маски, яскраві костюми, вогні й піротехніка. Крім того, на уявленнях вуличних театрів можна побачити акробатів, і клоунів, i жонглерів, і вуличних магів, та навіть музикантів. У цьому плані відповідальність перед глядачем за розуміння меж вуличного театру повністю лежить на плечах організаторів та режисерів вуличних театрів (Комарова, 2017: 40).

Історія виникнення та розвитку вуличної театральної сцени тісно пов'язана з режисерськими винаходами щодо організації театралізованих народних свят та обрядових вистав, що супроводжували людство практично на всіх стадіях його розвитку, починаючи 3 найбільш ранніх. Театралізовані вистави, що мали бути поставлені на цей час, включають у себе яскраві режисерські та акторські винаходи, широку палітру барв, костюмів, розмаїття різноманітного театрального дійства. Звісно, все це має своїм фундаментом режисуру, вишукану у традиціях театрального жанру, властивого тій чи інший місцевості, де мало відбиватися вуличне свято із застосуванням усього перерахованого вище.

Аналіз досліджень. Загальні питання розвитку режисури театральних постанов, що мають місце під час народних обрядів та свят, зокрема 3 точки зору аналізу вишуканості сценічної майстерності в контексті історії розвитку театральної сцени, широко представлені в дослідженнях А. Ю. Павлова, М. В. Комарової, Н. С. Московських, Д. П. Мойсеєвої та інших дослідників розвитку усіх сфер театрального мистецтва, починаючи 3 вуличного, святкового жанру. У своїх дослідженнях зазначені автори наголошують на типових закономірностях, що мають місце на різних стадіях розвитку театрального мистецтва, а також висвітлюють різні питання організації театрального дійства щодо режисури та постановки театральних сцен. Крім того, зазначені автори у своїх дослідженнях обговорюють питання дослідження історії театральної культури та розвитку сценічної майстерності, стосовно головних тенденцій формування традицій театралізованих постанов під час проведення народних свят та обрядів. У цілому зазначається, що режисура театралізованих постанов стосовно сценічного відображення народних обрядів та святкувань має величезне значення з точки зору формування певних умов розвитку театрального мистецтва та збагачення наявних театральних традицій.

Мета статті - визначення головних чинників оцінки режисури театральних свят та обрядів у контексті історії розвитку театру та формування належних умов щодо якісного відображення розвитку сценічної майстерності під час виконання сценічних постанов, характерних для української народної обрядової культури.

Виклад основного матеріалу. Звертаючись до вуличного театру як феномену культури, необхідно відзначити, що сьогодні відбувається очевидне відродження інтересу до творчої роботи акторів, музикантів, представників інших творчих професій у відкритих громадських простоpax. Цей очевидний тренд сучасності підтверджується висновками дослідників про те, що значимість вуличного театру як виду театральної культури, його естетики буде зростати. Однак сьогодні слід розглядати вуличні театри не тільки як особливу форму театральної постановки, коли «актори грають у вуличному просторі, яке спочатку не призначений для подання, а глядачі не платять за те, щоби побачити спектакль». Мова повинна йти про становлення нової культурної форми, яка інтегрує культурні практики і цінності сучасності. Як і інші форми сучасної індустрії розваг, вуличні театри - зразок яскравої та привабливої культурної форми, яка встановлює нові пріоритети соціального і особистого поводження, нові образи престижності, дає можливість для культурної самоідентифікації та творчої самореалізації особистості (Комарова, 2017: 47).

Сучасна театралізована вистава під час святкування народних свят на виконання обрядового дійства являє собою феномен, що знаходиться на перехресті багатовікових традицій культури окремого народу та тенденцій постмодерну, свят та повсякденних справ. Його коріння треба шукати, починаючи із сивої давнини, ще від Феспида, який ще в VI до н.е. грав на возі посеред ринку в Афінах, через творчість середньовічних жонглерів, містерії, масляні святкування, ярмаркові вистави, бульварні театри, політичний театр, через драматургію абсурду та вуличні демонстрації травня 1968 р. Безперервно трансформуючись й насичуючись новими смислами, вуличний театр відродився в теперішньому місті (Моисеева, 2014: 95). Водночас театралізоване святкове дійство кінця XX - початку XXI століть багато в чому можна вважати феноменом постмодерністської свідомості. Для нього характерні таки особливі риси, як змішування жанрів та стилів, звернення до художніх традицій при іронічному їх трактуванні, з'єднання непоєднуваного, відмова від ієрархічності, різноманітність інтердисциплінарних творчих форм, інакше кажучи форм, що виникають у процесі створення умов щодо взаємного проникнення різноманітних культур- 
них традицій, завдяки чому цей жанр стає дещо більшим, ніж тільки свідчення розвитку народної культури (Московских, 2015: 40).

Завдяки усім цим факторам театралізоване святкове дійство під час святкування народних свят та проведення святкових обрядів стає вельми затребуваним театральним жанром не тільки стосовно терен колишнього СРСР, а й у сучасній Європі. Тому зовсім не випадково, що особливо бурхливий розвиток мистецтво святкового театру отримало у Франції, де карнавальна життя, а разом із ним і розвиток усіх форм сміху досягли розквіту в XV-XVI ст. та залишили глибокий відбиток у культурі наступних поколінь. Згідно 3 результатами сучасних соціологічних досліджень, сьогодні, в епоху масового споживання продуктів «цифрової культури», святкове театральне шоу стоїть у числі найпопулярніших культурних практик французів, та його аудиторія постійно зростає. Кожен третій житель Франції старше 15 років регулярно відвідує вуличні вистави, в той час як публіка театральних залів становить лише 19\% французів. Ці факти яскраво свідчать про неабияке значення, що має режисура театралізованих народних свят та обрядів у сьогоденній культурі розвинутих країн та сучасній народній творчості.

Сучасний святковий театр має тісний зв'язок із суспільством та процесами, що мають місце у його повсякденному житті. Глядач у ньому займає позицію посередника між містом та сценою, між світом громадським та світом театральним. Він $\epsilon$ сполучною ланкою між вигадкою уявлення та проявами наявної реальності. І він же - необхідна складова частина для самого факту народження вистави. Сучасні театральні дослідники впевнені, що певному етапу розвитку суспільства відповідає певний етап розвитку театральної народної сцени, а також, відповідно, режисерських винаходів та формування культури режисерської діяльності загалом. Усе це сприяє розвитку відносин між театром та глядачами, формуванню взаємного зв'язку між режисурою та кінцевими результатами їі втілення у практичну площину театральної постановки (Колесникова, 2012: 45-46).

Історично вуличний театр у багатьох культурах складався та розвивався як фольклорний театр із властивими йому розважальними та виховними (наративними) функціями. Однак на початку XX століття вуличний святковий театр набуває нові функції соціальної інтеграції, він стає більш формою соціального спілкування, ніж просто формою мистецтва. Досить часто дослідники історії театральної сцени у Свропі та США відмічають той факт, що театр не буває повністю або частково залученим до боротьби певних ідеологічних систем, частіше за все йому бувають притаманні риси боротьби за звільнення робочого класу від надмірної його експлуатації, антиколоніальної боротьби та просування революційних ідей. Варто відзначити, що саме у святкового народному театрі глядач $є$ найбільш зближеним із твором мистецтва, постановка якого відбувається у сценічних умовах. Падіння «четвертої стіни», яка відділяє актора від публіки, призвело до перегляду ролей суб'єкта та об'єкта театрального дійства (Фомичева, 2016: 10-11). У вуличному театрі актор і аудиторія - партнери. У науковій літературі тип глядача вуличного театру називають складовим словом «spect'acteur», що означає одночасно «актор» й «глядач». Вулична святкова вистава завжди $є$ інтерактивною. Спільна творчість актора і глядача є складним, але необхідним елементом для того, щоб театр «відбувся». У мобільному виставі «Листоноші» театру «No Tunes Internation» артисти, що зображують співробітників пошти, переміщаються по місту в супроводі глядачів та розносять листи. Несправжні листоноші стукають у двері городян, що нічого не підозрюють, та вголос зачитують «адресатам» послання 3 освідченнями в любові або невірності, скарги, повідомлення від податкової служби, судових приставів та інше. Подання, яке має лише загальну канву, засновану на заздалегідь написаних текстах листів, будується в основному на імпровізованих діалогах із жителями та глядачами, їхніх непередбачуваних людських реакціях на те, що відбувається. Таким чином, цей спектакль, який існує в репертуарі театру вже більше десяти років, унікальний у кожному своєму виконанні (Моисеева, 2014: 97).

Режисура театралізованих свят та обрядів у контексті має спиратися на передбачення реакції глядача на цей чи інший художній прийом, що застосовується в ході постанови театрального дійства. Загалом, технологія організації вуличної театральної постановки включає в себе цілеспрямований вибір місця проведення вистави, організацію активності акторів і глядачів, вибір джерел фінансування. Святкова театральна постанова може відбуватися в будь-якому многолюдному місці - торгівельному центрі, місцевому парку чи саду, місцевому майдані, в зоні відпочинку та атракціонів. У подібних виставах бувають залучені актори різних спеціалізацій та рівня підготовки: від окремих вуличних музикантів до добре організованих театральних компаній або груп, що експериментують із новими театральними просторами та просувають нові художні напрями та 
режисерські винаходи. Іноді театралізовані постановки відбуваються в рамках вуличних фестивалів, дитячих свят або різноманітних парадів. Але все ж частіше вуличні театри показують готові уявлення, переїжджаючи з одного місця на інше 3 однією й тією ж постановкою, в надії отримати трохи «випадкових» монет у кинутий поруч капелюх (Павлов, 2012: 300).

У сучасному місті святкове та обрядове театральне шоу дуже часто $є$ засобом групового спілкування, що вельми ефективно у середовищі, де превалюють засоби опосередкованої комунікації. Тим часом колективне спілкування, що $е$ своєрідним емоційним регулятором, необхідно людині, адже «індивідуалізована культура є лише тонкою плівкою над стихією маси з її потужними пластами колективного несвідомого» (Черкашенинов, 2019: 15-16).

Історія розвитку сучасного театру в контексті режисерських винаходів щодо створення постанов під час народних святкувань та відправлення обрядових дійств знає багато прикладів нестандартного підходу окремих режисерів до питань театральної постановки та залучення до цього процесу засобів, що раніше не були відомі широкій публіці. Так, наприклад, у 1990 р. у рамках Авіньйонського фестивалю на очах у багатотисячної аудиторії театр представляє грандіозну «Справжню історію Франції». Перед глядачами одна за одною перегортаються сторінки гігантського фоліанта, побудованого за зразком дитячих книг-панорам із тривимірним зображенням. Дванадцять сторінок книги являють собою сцени з різних епох, причому історичні особи - добре знайомі усім персонажі. Історичні образи змінюють один одного не в хронологічному порядку, а хаотично, подібно до уривчастих спогадів: сцену Божественного одкровення Жанни д’Арк про іiі велике призначення змінюе сторінка про перші подорожі по країні французьких робітників, які отримали влітку 1936 року свої перші оплачувані відпустки. Лише тільки затихають звуки вибухів та пострілів фашистських загарбників, що стрімко просуваються по території Франції, як перед глядачами постає «король-сонце» у всій своїй красі. Ось Наполеон задумливо крокує уздовж стін палаючого засніженого Московського Кремля, й бій Верцінгеторікса $з$ римськими легіонерами. Ось Карл Великий вручає Роланду меч Дюрандаль, та вже гримить революція 1789 p.

Вистава-калейдоскоп об'єднала історичні персонажі та епохи, якими вони відображені у свідомості багатьох поколінь французів, де міф невіддільний від реальності. Історична достовірність тут поступається місцем ідеалізованим, емоційно забарвленим образам. Однак сама назва вистави каже про те, що справжня історія - це та, яка живе в колективній пам'яті народу. Те ж саме можна стверджувати стосовно історії розвитку театральних постанов у контексті режисерського підходу до створення театральних спектаклів у різні історичні часи (Сазонова, 2015: 85).

Сьогодні режисура театралізованих свят та народних обрядів стає вельми важливим аспектом із точки зору визначення основних напрямків розвитку сучасного театру. Звернене до найширшої аудиторії, мистецтво сучасного театру позиціонує глядача як партнера, спонукає його до творчості, реалізуючи тим самим принципи культурної демократії, які є пріоритетними для сучасної культурної політики європейських країн. Під час широкого розповсюдження сучасних засобів масової комунікації святковий театр та подальший розвиток сценарної майстерності виконавців мають велике значення з точки зору формування культури сприйняття театрального дійства глядачами та самими виконавцями. Режисура сучасного театру стрімко розвивається згідно з віяннями сучасної інформатизованої епохи, що накладає свій відбиток на сприйняття театрального дійства та розповсюдження культури загалом. На час вуличної вистави місто перетворюється, зникають діючі соціальні бар'єри та обмеження. У силу вступають закони «нереального» карнавального світу, головним із яких є саме свобода в усіх її проявах. Для глядача, як і для артиста, вулична вистава $\epsilon$ унікальним творчім досвідом, особливим ігровим середовищем, у якому діють свої закони та правила, які зумовлюють сприйняття дійства його глядачами та учасниками з точки зору його впливу на їхню свідомість та здатність віддати належне застосовуваним режисерським засобам постанови.

Висновки. Історія розвитку сучасного театру має багато прикладів змінювання чинників побудови концепцій формування режисерської уяви щодо різноманітних аспектів реалізації театральної постановки під час проведення народних свят та обрядових дійств. Формування сценарної майстерності виконавців та постановників театральних вистав відбувалося за умови впливу на історію театру соціальних явищ, характерних для певних епох та умов існування окремих державних структур, що накладає свій певний відбиток на структуру розвитку театральної сцени загалом.

Аналіз історії та сучасних форм побутування жанру святкового та обрядового театрального дійства яскраво демонструє, що в кінці XX та на початку XXI століття режисура святкового театру 
повернула до себе суспільну увагу, що було зумовлено зміною іiї функцій як особливої культурної форми. При цьому вуличні театри залишаються в постійному пошуку нових форм художньої виразності, які не знімають із порядку денного необхідність естетичного осмислення досягнень режисури вуличних вистав, акторської роботи та всіх інших складових частин цього актуального виду театрального мистецтва.

На жаль, слід констатувати, що ще й досі багато питань розвитку, становлення та формування вуличного святкового театру недостатньо вивчені та вимагають детального опрацювання. Але все ж слід виділити факт того, що видо- вище у структурі сучасної культури постмодерну займає все більше місце в культурологічному аспекті, а режисура театральної постанови в умовах створення спектаклю під час святкування народного свята або відправлення обрядового дійства повною мірою $є$ елементами концентрації видовищного мистецтва в різноманітних його проявах. Тому подальше вивчення різноманітних аспектів розвитку режисури театралізованих свят та постанов народних обрядових дійств здатне сприяти найбільш глибокому розумінню культурної спадщини окремого народу та основних етапів його культурного розвитку в певних історичних соціально-культурних умовах.

\section{СПИСОК ВИКОРИСТАНИХ ДЖЕРЕЛ}

1. Колесникова А. А. «Условный театр» В. Мейерхольда до 1917 года: Рождение и трансформация. Известия Пензенского государственного педагогического университета им. В. Белинского. 2012. № 27. С. 41-48.

2. Комарова М. В. Уличный театр в пространстве современной культуры. Культура и образование: Научноинформационный журнал вузов культуры и искусств. 2017. № 3. С. 46-53.

3. Моисеева Д. П. Современный уличный театр как опыт демократизации культуры (на примере Франции). Вестник Московского университета. Серия 19: Лингвистика и межкультурная коммуникация. 2014. № 2. С. $95-101$.

4. Московских Н.С. Уличный театр как форма урбанизации зрелищного искусства. Вестник Санкт-Петербургского государственного института культуры. 2015. № 5. С. 39-44.

5. Павлов А. Ю. Культурологические аспекты истоков и функционирования улично-площадного театра. Омский научный вестник. 2012. № 4(111). С. 298-301.

6. Сазонова В. А. В. Э. Мейерхольд и его театральное наследие. Неофилология. 2015. № 1(1). С. 81-90.

7. Иконникова С. Н., Большакова В. П. Теория культуры. Санкт-Петербург : Питер, 2008. 592 с.

8. Фомичева О. Б. Предпосылки открытия биомеханики как системы для подготовки актеров театра будущего. Театр. Живопись. Кино. Музыка. 2016. № 2. С. 9-34.

9. Черкашенинов Л. Ф. Проблемы времени и профессиональный инструментарий специалиста режиссуры праздников. Ученые записки. 2019. № 1(19). С. 11-27.

\section{REFERENCES}

1. Kolesnikova A. A. "Uslovnyiy teatr" V. Meyerholda do 1917 goda: Rozhdenie i transformatsiya ["Conditional Theater" by V. Meyerhold before 1917: Birth and transformation]. Izvestiya Penzenskogo gosudarstvennogo pedagogicheskogo universiteta im. V. Belinskogo, 2012, Nr. 27, pp. 41-48 [in Russian].

2. Komarova M. V. Ulichnyiy teatr $\mathrm{v}$ prostranstve sovremennoy kulture [Street theater in the space of modern culture]. Kultura i obrazovanie: Nauchno-informatsionnyiy zhurnal vuzov kulturyi i iskusstv, 2017, $\mathrm{Nr} 3$, pp. 46-53 [in Russian].

3. Moiseeva D. P. Sovremennyiy ulichnyiy teatr kak opyit demokratizatsii kulturyi (na primere Frantsii) [Modern street theater as an experience of democratization of culture (on the example of France)]. Vestnik Moskovskogo universiteta. Seriya 19: Lingvistika i mezhkulturnaya kommunikatsiya, 2014, $\mathrm{Nr} 2$, pp. 95-101 [in Russian].

4. Moskovskih N. S. Ulichnyiy teatr kak forma urbanizatsii zrelischnogo iskusstva [Street theater as a form of urbanization of the performing arts]. Vestnik Sankt-Peterburgskogo gosudarstvennogo instituta kulturyi, 2015, Nr 5, pp. 39-44 [in Russian].

5. Pavlov A. Yu. Kulturologicheskie aspektyi istokov i funktsionirovaniya ulichno-ploschadnogo teatra [Cultural aspects of the origins and functioning of the street-square theater]. Omskiy nauchnyiy vestnik, 2012, Nr 4 (111), pp. 298-301 [in Russian].

6. Sazonova V. A. V. E. Meyerhold i ego teatralnoe nasledie [V. E. Meyerhold and his theatrical heritage]. Neofilologiya, 2015, Nr 1 (1), pp. 81-90 [in Russian].

7. Ikonnikova S. N., Bolshakova V. P. Teoriya kulturyi [Theory of culture]. Sankt-Peterburg: Piter, 2008. 592 p. [in Russian].

8. Fomicheva O. B. Predposyilki otkryitiya biomehaniki kak sistemyi dlya podgotovki akterov teatra buduschego [Prerequisites for the discovery of biomechanics as a system for training actors of the theater of the future]. Teatr. Zhivopis. Kino. Muzyika, 2016, Nr 2, pp. 9-34 [in Russian].

9. Cherkasheninov L. F. Problemyi vremeni i professionalnyiy instrumentariy spetsialista rezhissuryi prazdnikov [Problems of time and professional tools of a specialist in directing holidays]. Uchenyie zapiski, 2019, $\mathrm{Nr} 1$ (19), pp. 11-27 [in Russian]. 